\title{
Expression of TRAIL receptors in human autoreactive and foreign antigen-specific $T$ cells
}

\author{
U Wendling ${ }^{1}$, H Walczak², J Dörr', C Jaboci', M Weller ${ }^{3}$, \\ PH Krammer ${ }^{2}$ and F Zipp*,1 \\ ${ }^{1}$ Department of Neurology, Division of Neuroimmunology, Charité, Berlin, \\ Germany \\ 2 German Cancer Research Centre, Heidelberg, Germany \\ ${ }^{3}$ Department of Neurology, Division of Neurooncology, University of Tübingen, \\ Germany \\ * Corresponding author: F Zipp, Department of Neurology, Division of \\ Neuroimmunology, University Hospital Charité, Campus Virchow, \\ Forschungshaus, 2.0G, R. 535, Augustenburger Platz 1, 13353 Berlin, \\ Germany, Tel: 004930450 59718; Fax: 004930450 59718; \\ E-mail: frauke.zipp@charite.de
}

Received 27.12.99; revised 25.2.00; accepted 6.3.00

Edited by ML Gougeon

\begin{abstract}
Deletion of $\mathrm{T}$ cells due to apoptosis induction is a regulatory mechanism in the human immune system that may be impaired in autoimmune diseases such as multiple sclerosis (MS). Involvement of the apoptosis-mediating CD95/CD95 ligand system in MS has been demonstrated. Here, we report that (auto)antigen-specific human T cells are not killed in vitro by soluble TNF-related apoptosis-inducing ligand (TRAIL) although expressing death-inducing receptors, TRAIL receptor 1 (TRAIL-R1) and TRAIL-R2. Apoptosis was assessed by caspase activation and DNA fragmentation, receptor expression was detected by RT-PCR and flow cytometry. The (auto)antigen-specific $T$ cells were also resistant to specific TRAIL-R1/TRAIL-R2-directed induction of apoptosis, indicating that coexpression of the truncated TRAIL-R3 and TRAILR4 in these $T$ cells is not responsible for the observed resistance. Upon stimulation, levels of death-inducing TRAIL receptors decreased whereas TRAIL was up-regulated on the cell surface. In contrast to CD95, the role of TRAIL receptors in MS might not involve regulation of $\mathrm{T}$ cell vulnerability. Cell Death and Differentiation (2000) 7, 637-644.
\end{abstract}

Keywords: TRAIL; apoptosis; T lymphocytes; multiple sclerosis

Abbreviations: TRAIL, TNF-related apoptosis-inducing ligand; Trail-R, TRAIL receptor; MS, Multiple Sclerosis; EAE, experimental autoimmune encephalomyelitis; MBP, myelin basic protein; TT, tetanus toxoid

\section{Introduction}

Apoptotic death of lymphocytes is involved in the maintenance of tolerance to self antigens. ${ }^{1,2}$ The mechanism of $\mathrm{T}$ cell control, namely activation-induced $T$ cell death, critically depends on the CD95 (APO-1/Fas) pathway. ${ }^{3-5}$ In particu- lar, there is evidence for the pathogenic and therapeutic role of CD95-mediated apoptosis in autoimmune diseases such as Multiple Sclerosis (MS). ${ }^{6-8}$ In the course of this disease, myelin-specific $T$ cells invade the central nervous system (CNS) and promote demyelination. Induction of T cell death, especially via CD95-mediated apoptosis, would decrease T cell numbers, reduce invading T cells and thus autoimmunemediated tissue damage. This regulatory process is effective during recovery ${ }^{9}$ and experimental treatment of the MS model disease, experimental autoimmune encephalomyelitis (EAE). ${ }^{10-12}$ It has, however, been difficult to reconcile the protection from active EAE in mice lacking functional CD95 (Ipr) or CD95 ligand $(g / d)^{13-15}$ with the increasing evidence for impaired CD95-dependent T cell elimination in MS. ${ }^{16-20}$ Thus, other death receptor/ligand systems might be involved in the pathogenesis. Recently, it was demonstrated that gld mice with passive EAE, induced by transfer of autoreactive $T$ cells, developed prolonged clinical signs when immunized with wildtype T cells. ${ }^{21}$ Thus, in the passive EAE model, inhibiting the CD95 ligand results in reduced disease remission. The latter clearly indicates the role of CD95-mediated apoptosis in the regulation of $T$ cells in EAE. However, it is still not fully understood under which conditions $\mathrm{T}$ cells are rendered susceptible to apoptosis. ${ }^{8,22,23}$ Over the past few years it has become evident that there are several other apoptosisassociated receptor/ligand interactions besides the CD95/ CD95 ligand system involved in the fate of a cell, in particular the recently described TNF-related apoptosis-inducing ligand (TRAIL) receptor/TRAIL system, mainly including TRAIL; 24,25 the death-inducing receptors TRAIL receptor 1 (TRAIL-R1) (also referred to as DR4) ${ }^{26}$ and TRAIL-R2 (also referred to as DR5); ${ }^{27,28}$ and the truncated TRAIL receptors TRAIL-R3 (also referred to as DcR $1,{ }^{27}$ TRID $^{29}$ or LIT) ${ }^{30,31}$ and TRAIL-R4 (also referred to as DcR2). ${ }^{32,33}$ Interactions between TRAIL and truncated TRAIL receptors are considered to physiologically block apoptosis ${ }^{27,29-32}$ which might thus contribute to the pathogenesis of autoimmunity. However, it is not known whether and, if so, how the TRAIL/TRAIL receptor system participates in the pathogenesis of MS. So far, contradictory reports have been published concerning the susceptibility of non-specifically stimulated $T$ cells to soluble recombinant TRAIL. ${ }^{34,35}$

Here, we studied the expression pattern and modulation of the TRAIL receptor/TRAIL system in human myelin- and foreign antigen-specific $T$ cells of MS patients and healthy donors. Upon stimulation, death-inducing TRAIL receptors were down-regulated whereas TRAIL itself was upregulated. The $T$ cells were not susceptible to apoptosis induced by three different soluble TRAIL preparations although we found expression of both apoptosis-mediating receptors, TRAIL-R1 and TRAIL-R2. Moreover, these T cells were also resistant to antibody-mediated TRAIL-R1/ TRAIL-R2-specific apoptosis. This argues against the coexpression of the truncated TRAIL receptors TRAIL-R3 
and -R4 being responsible for the protection of the (auto)antigen-specific T cells.

\section{Results}

\section{No induction of apoptosis in human antigen-specific $T$ cells by soluble TRAIL}

First, we examined whether human $\mathrm{T}$ cells are susceptible to TRAIL-induced apoptosis. Antigen-specific $T$ cell lines, recognizing the myelin antigen, myelin basic protein (MBP) or the foreign antigen tetanus toxoid (TT) (see Table 1), were resistant to three different preparations of soluble recombinant TRAIL, whereas all of these TRAIL preparations induced apoptosis in Jurkat T lymphoma cells. This is shown in Figure 1 for the functionally active leucine zipper(LZ)-TRAIL measured by caspase activation (Figure 1a) and DNA fragmentation (Figure 1b). No differences in TRAIL-mediated apoptosis susceptibility between MBPand TT-specific $T$ cell lines and between those derived from patients and healthy individuals were observed. Caspase activation and DNA fragmentation in Jurkat $T$ lymphoma cells induced by soluble LZ-TRAIL confirmed the functional activity of this TRAIL preparation (see Figure $1 \mathrm{a}, \mathrm{b})$. Even in the presence of cycloheximide $(10 \mathrm{ng} / \mathrm{ml}) \mathrm{no}$ induction of apoptosis by soluble LZ-TRAIL was found (data not shown).

\section{Human antigen-specific $T$ cells express death-inducing TRAIL receptors}

We asked whether the unresponsiveness of the human antigen-specific T cells to TRAIL-induced apoptosis was due to a lack of TRAIL receptor expression. Therefore, antigenspecific $T$ cell lines were analyzed for presence of deathinducing TRAIL receptors. We isolated CDNA from different antigen-specific $\mathrm{T}$ cell lines and tested for presence of message for TRAIL-R1 and -R2 (Figure 2). All T cell lines tested were found positive for both death-signaling TRAIL receptors, although the expression level revealed a great

Table 1 Human antigen-specific $T$ cell lines

\begin{tabular}{lcc}
\hline T cell line & Antigen specificity & Origin \\
\hline AH2 & MBP & MS \\
DE1 & MBP & MS \\
DE3 & MBP & MS \\
SC1 & MBP & MS \\
AV2 & MBP & healthy individual \\
AV4 & MBP & healthy individual \\
W2 & MBP & healthy individual \\
U5 & MBP & healthy individual \\
FZ18 & TT & healthy individual \\
FZ20 & TT & healthy individual \\
MB3 & TT & healthy individual \\
MB5 & TT & healthy individual \\
MB7 & TT & healthy individual \\
MB15 & TT & healthy individual \\
\hline
\end{tabular}

All $T$ cell lines showed a stimulation index $>3(A H, D E, S C, A V, W, U, F Z, M B$ are different individuals). The MBP-specific $T$ cell lines are T-Helper-1- or Thelper-0-like, whereas all TT-specific T cell lines display the T-helper-0 status

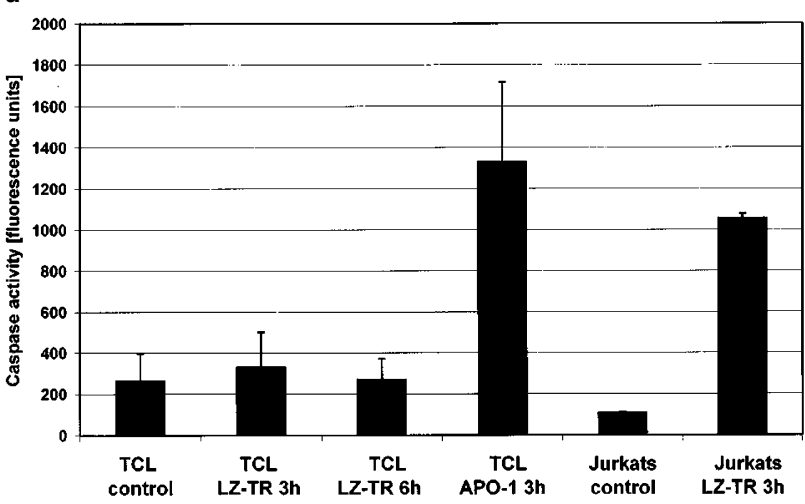

b

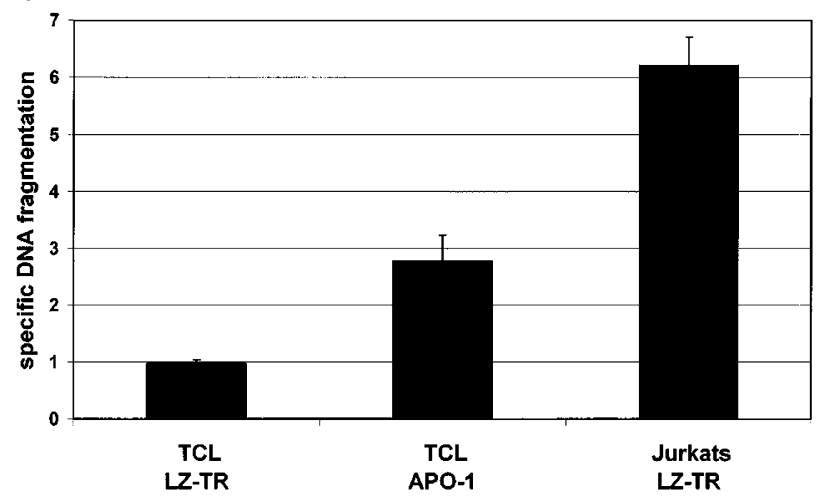

Figure 1 No induction of apoptosis in human antigen-specific $T$ cells by soluble TRAIL. Antigen-specific T cell lines (TCL) AV4, W2, AH2, MB3, MB5, MB7 and MB15 and as positive control Jurkat T lymphoma cell line were treated with soluble functionally active trimerized TRAIL (LZ-TR) $(2 \mu \mathrm{g} / \mathrm{ml})$ and as positive control for TCL with APO-1 $(1 \mu \mathrm{g} / \mathrm{ml})$ plus protein A $(10 \mathrm{ng} / \mathrm{ml})$. (a) Caspase activity was measured at $3 \mathrm{~h}$ exposure to the apoptosis stimuli (at $3 \mathrm{~h}$ maximum activity was found for most apoptosis-inducing stimuli), the exposure time for LZ-TR was extended to $6 \mathrm{~h}$ in order to detect a delayed peak. Data are expressed as mean fluorescence units and standard error of the mean (S.E.M.), each assay was performed in triplicates (see Materials and Methods). (b) Specific DNA fragmentation was measured by flow cytometry at $24 \mathrm{~h}$ and is demonstrated as mean and S.E.M. (see Materials and Methods) with control values of $17.0 \%$ apoptotic cells (S.E.M. 3.0) for TCL and $13.8 \%$ for Jurkat cells (S.E.M. 1.4)

TRAIL-R1

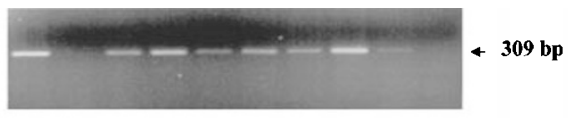

TRAIL-R2

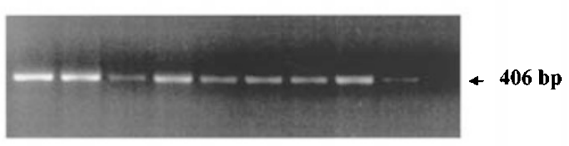

G3PDH

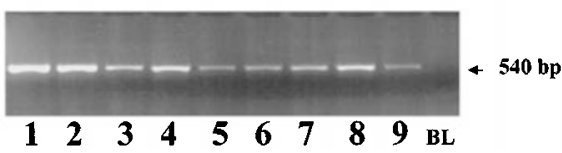

Figure 2 Transcription of death-inducing TRAIL receptors in human antigenspecific $T$ cells assessed by RT-PCR. Expression of TRAIL receptors was analyzed by RT - PCR in seven human T cell lines (lanes 3-9; AV4, U5, W2, $F Z 18, F Z 20, M B 5, M B 15)$ and two human glioma lines (lane 1: LN18, lane 2: T98G). Bands represent the product of RT-PCR for TRAIL-R1, 2, and reference gene G3PDH (for details, see Materials and Methods) 
TR1

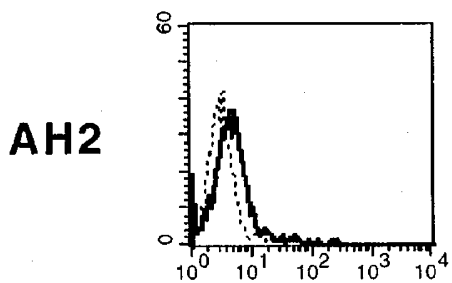

A V 2

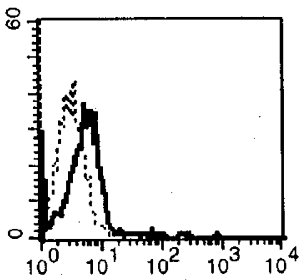

A V 4

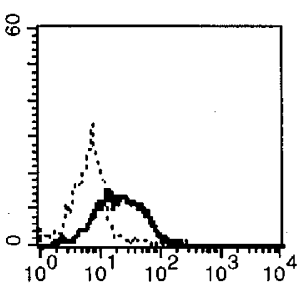

LN18
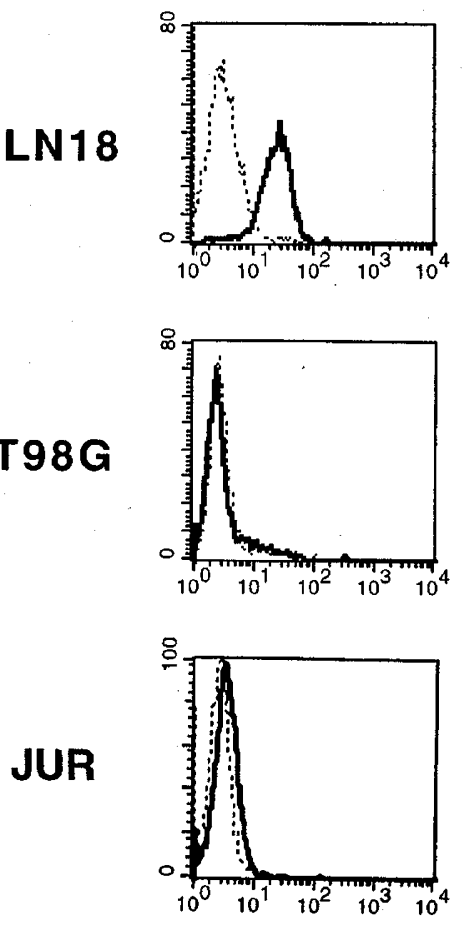

TR2
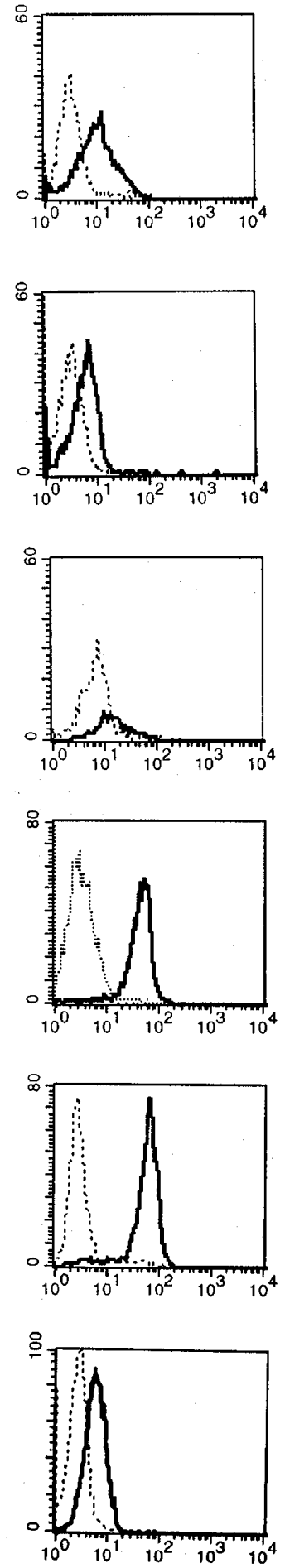

TR3
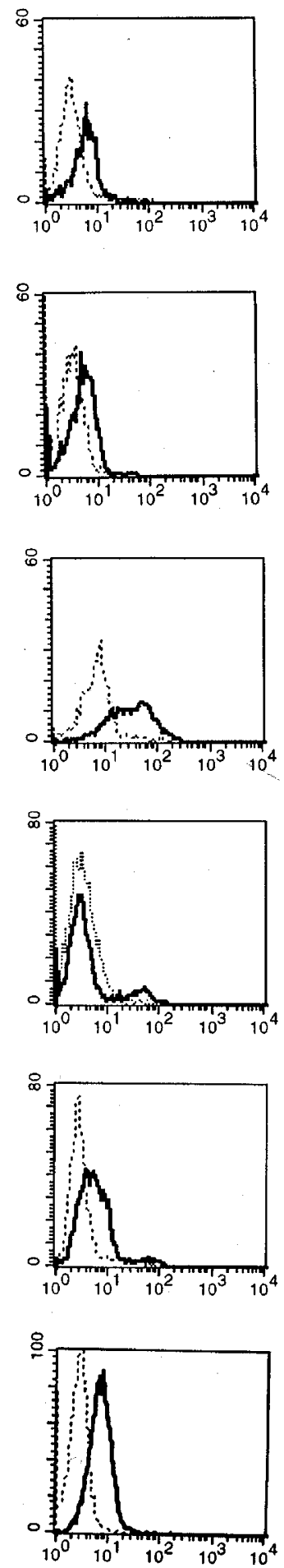
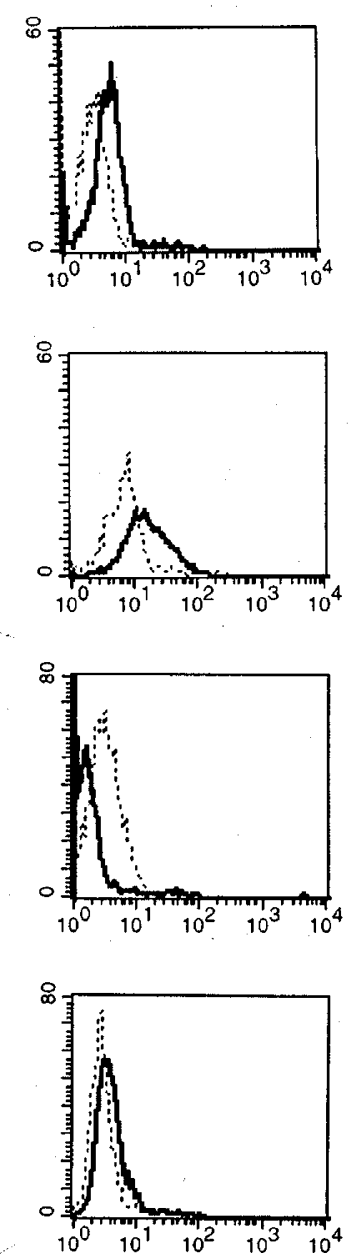

\section{TR4}
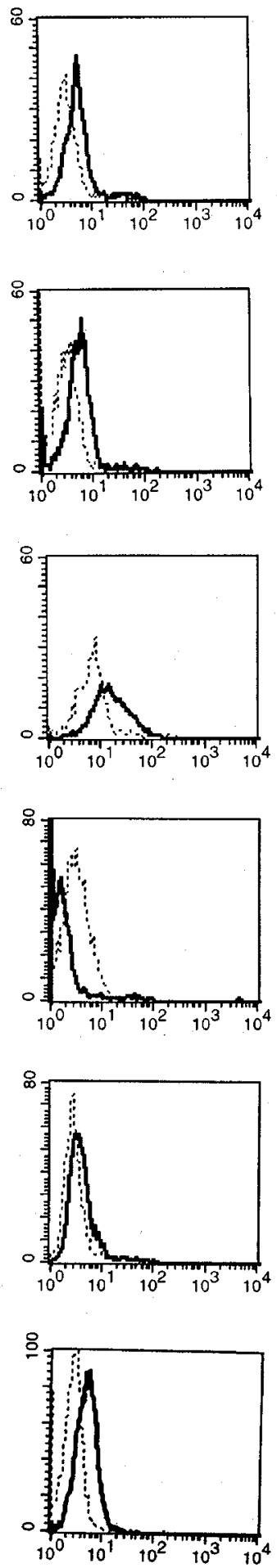

Figure 3 Human antigen-specific T cells express all TRAIL receptors. Cell surface expression of TRAIL receptors in three representative human MBP-specific T cell lines (AH2, AV2, AV4), in comparison TRAIL-susceptible human glioma cell lines (LN-18, T98G) and a human T cell lymphoma line (Jurkat; JUR) was performed by flow cytometry (see Materials and Methods). Data are expressed in a fluorescence histogram overlay depicting TRAIL receptor staining (solid line) versus negative control staining (dotted line) 
variability of expression between the different $T$ cell lines. No significant difference of receptor RNA levels was observed between MBP- and TT-specific T cell lines.

\section{Co-expression of death-inducing and death-blocking TRAIL receptors in human antigen-specific $T$ cells}

In order to find out whether the resistance of antigen-specific $T$ cells is due to coexpression of inducible and blocking TRAIL receptors we also investigated the distribution of these receptors. We found expression of all TRAIL receptors in antigen-specific T cells on the RNA (shown for TRAIL-R1 and TRAIL-R2 in Figure 2, data for TRAIL-R3 and TRAIL-R4 are not shown) and the protein level (Figure 3). In Figure 3 the surface expression pattern of three $T$ cell lines is shown as representative examples. The TRAIL receptor expression on the cell surface was tested with monoclonal antibodies specific for the four TRAIL receptors 1-4. Glioma cell lines LN18 and T98G, previously investigated regarding RNA levels of the TRAIL receptors ${ }^{36}$ and the Jurkat $T$ cell lymphoma line are demonstrated in comparison. We found a stronger surface expression of at least one death-inducing TRAIL receptor in these glioma cells than in the antigenspecific $T$ cell lines, whereas Jurkat cells displayed a receptor pattern similar to the $T$ cell lines. As shown for the RNA level (Figure 2) TRAIL-R1 is not expressed on the cell surface of T98G. The cell surface expression of the truncated TRAIL-R3 and -R4 was, however, markedly higher in the antigenspecific T cells than in T98G and was not present in LN18.

All $T$ cell lines tested displayed the four TRAIL receptors. The level of surface expression varied between $T$ cell lines. Yet, there was no consistent difference between MBP- and TT-specific T cell lines. The expression of the death-inducing TRAIL receptors was similar in T cell lines derived from MS patients as in those derived from healthy donors. However, we observed a higher expression of TRAIL-R3 in a panel of T cell lines derived from patients (specific fluorescence intensity $(\mathrm{SFI}) \pm$ S.E.M. $=31.5 \% \pm 3.9)$ compared to those from healthy donors $(\mathrm{SFI} \pm$ S.E.M. $=14.1 \% \pm 7.0)$.

\section{Agonistic TRAIL-R1 and TRAIL-R2 antibodies induce apoptosis in Jurkat but not in human antigen-specific $T$ cells}

In order to address the question whether the truncated TRAILR3 and TRAIL-R4 are capable of protecting the antigenspecific T cells from TRAIL-induced apoptosis, we compared the effect of LZ-TRAIL to the effect of immobilized agonistic TRAIL-R1/TRAIL-R2 antibodies. Therefore, antigen-specific $T$ cells and Jurkat $T$ lymphoma cells as positive control were incubated with LZ-TRAIL, immobilized agonistic TRAIL-R1/ TRAIL-R2 antibodies and the combination of these TRAILmediated apoptotic stimuli (Figure 4). Whereas TRAIL-R1/ TRAIL-R2-specific apoptosis was comparable to LZ-TRAILtriggered apoptosis in Jurkat cells, the myelin and foreign antigen-specific $T$ cells were resistant to both apoptosis stimuli. Further, the combination of antibody-and ligandmediated apoptosis did not act synergistically in Jurkat $T$ cells. As expected, the antigen-specific $\mathrm{T}$ cells also stayed resistant when incubated with the combination of apoptosis stimuli.

\section{TRAIL and death-inducing, but not truncated TRAIL receptors are regulated upon activation of antigen-specific $T$ cells}

The regulation of TRAIL and its receptors in the human antigen-specific $\mathrm{T}$ cells upon activation was tested by RT-

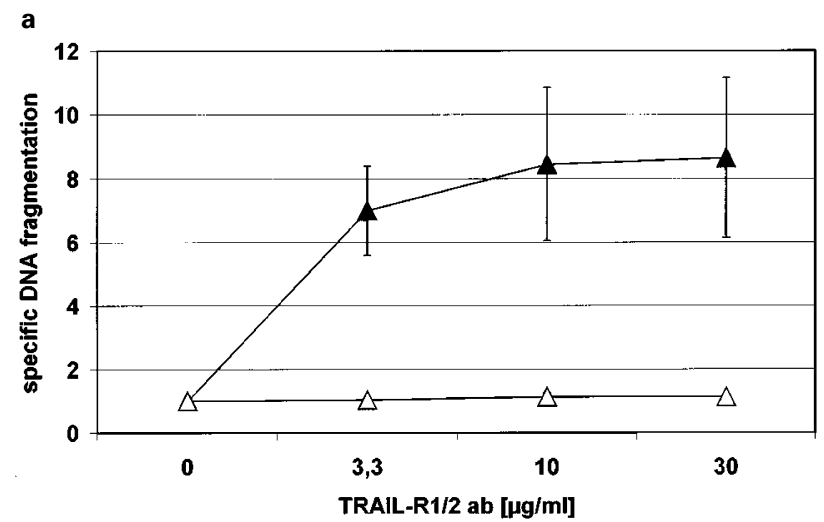

b

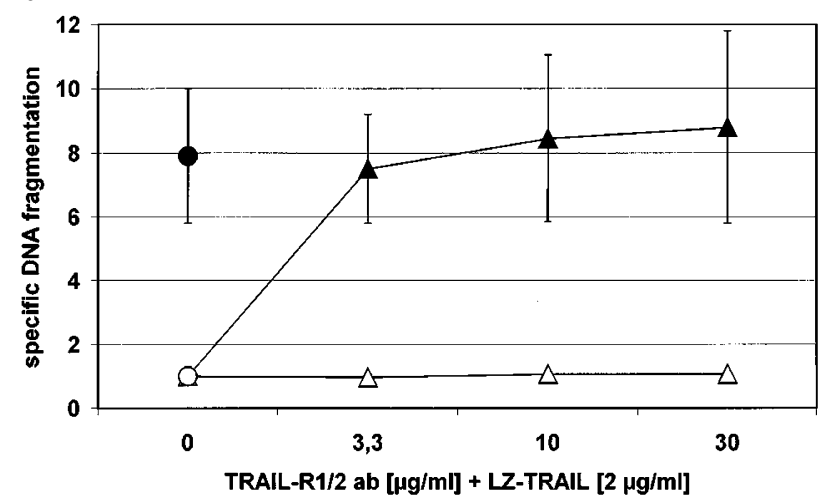

c

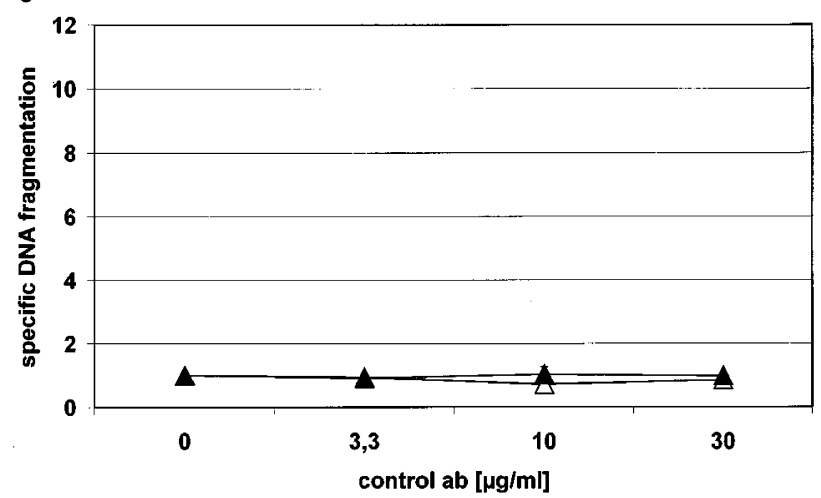

Figure 4 No induction of apoptosis by TRAIL-R1- and TRAIL-R2 mediated signal. Human antigen-specific $T$ cell lines (open symbols) or Jurkat $T$ lymphoma cells (closed symbols) were treated with (a) immobilized agonistic TRAIL-R1/TRAIL-R2, (b) either with LZ-TRAIL $(2 \mu \mathrm{g} / \mathrm{ml})$ alone (circles) or the combination of ligand and antibodies (triangles), or (c) an irrelevant control mouse IgG1 antibody alone. After $24 \mathrm{~h}$ specific DNA fragmentation was measured (for details, see Materials and Methods). Control values for Jurkat cells were $15.9 \%$ (S.E.M. 0.9 ) and $16.3 \%$ (S.E.M. 0.4 ) for TCL 
a

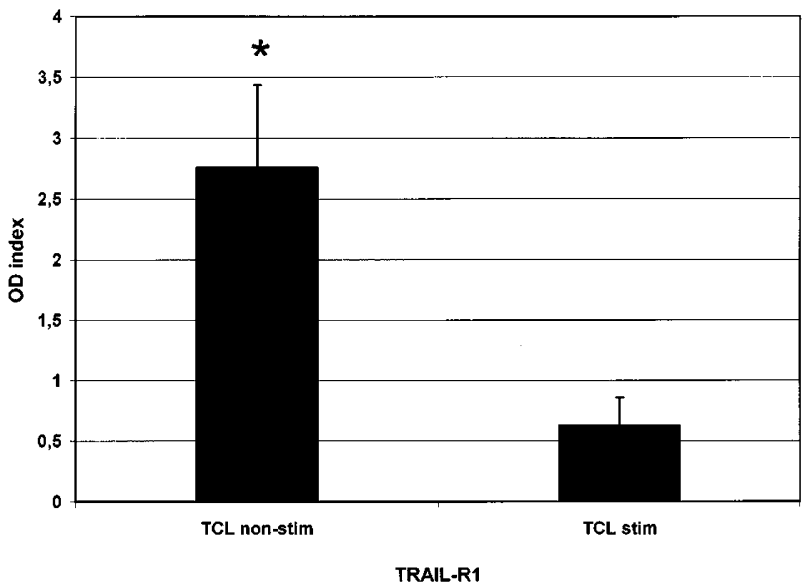

b

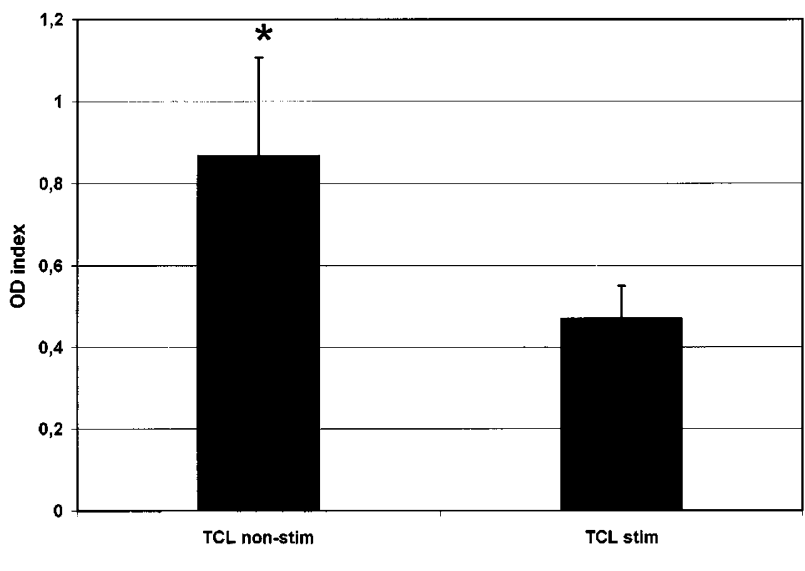

TRAIL-R2

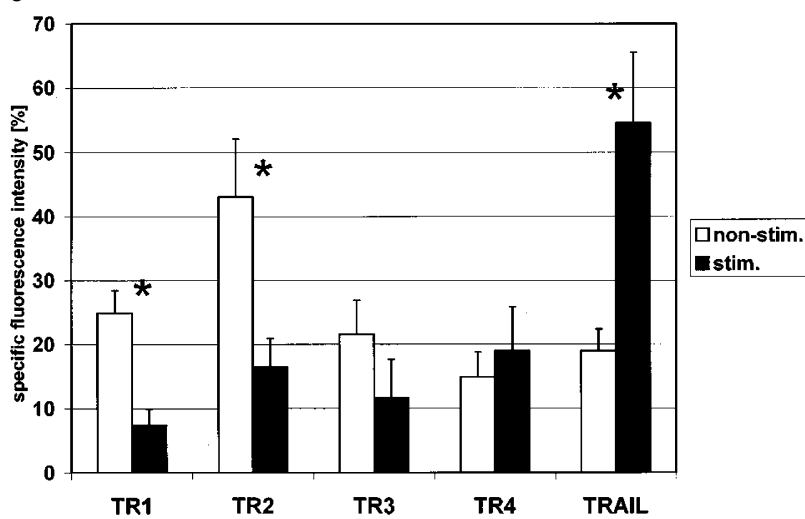

Figure 5 TRAIL-receptors 1 and 2 are down-regulated on various T cell lines upon T cell receptor stimulation whereas TRAIL is up-regulated. TRAIL-R1-4 and TRAIL were analyzed in human antigen-specific $T$ cell lines from healthy donors (AV2, AV4, FZ18, MB15) and MS patients (AH2, DE1, DE3, SC1) on the RNA and protein level prior and after activation of $T$ cells via immobilized anti-CD3 and anti-CD28. (a,b) Transcripts were detected by PCR using primers specific for TRAIL-R1-4 and G3PDH as control. Semiquantitative analysis of TRAIL-R1 (a) and -R2 (b) RT-PCR product levels is expressed as mean OD index and S.E.M. (for details see Materials and Methods). ( ${ }^{\star} P<0.05$, Mann-Whitney $U$-test. (c) Cell surface expression was detected by flow cytometry (see Materials and Methods). Data is expressed as specific fluorescence intensity and represents the mean and S.E.M. of five MBPspecific and 2 TT-specific $T$ cell lines. $\left({ }^{*} P<0.05\right.$, Mann-Whitney $U$-test)
PCR and flow cytometry employing antigen-specific $T$ cells that were activated by immobilized anti-CD3 and anti-CD28 antibodies to avoid contamination by antigen-presenting cells. In Figure 5 mean levels of TRAIL-R1 (Figure 5a) and -R2 (Figure $5 \mathrm{~b}$ ) measured by RT-PCR before and $24 \mathrm{~h}$ after stimulation are depicted for seven $T$ cell lines (three from MS patients and four from healthy donors). These death-signaling TRAIL-R1 and -R2 are down-regulated on the RNA level when $T$ cells are activated. Figure $5 \mathrm{c}$ demonstrates the cell surface expression of the entire TRAIL receptor/TRAIL system as measured by flow cytometry. Expression levels of (cell surface) accessible death-inducing TRAIL receptors 1 and 2 decreased upon T cell stimulation - at the same time TRAIL surface expression was up-regulated. No significant regulation was observed for TRAIL receptors 3 and 4 . Further, there was no consistent difference between MBP- and TT-specific T cell lines and between $T$ cell lines derived from MS patients and those from healthy donors in the regulation of the TRAIL receptors in response to activation.

\section{Discussion}

In recent years it became evident that one major regulatory mechanism of autoimmune diseases such as multiple sclerosis is apoptosis. Natural mouse mutants carrying mutations in the CD95 (Ipr) or CD95 ligand $(\mathrm{g} / \mathrm{d})$ genes in which activation-induced cell death is impaired exhibit lymphoproliferative and autoimmune syndromes. ${ }^{37}$ Further, children with CD95-gene defects suffer from similar autoimmune disorders. ${ }^{38-41}$ Autoreactive myelin-specific $\mathrm{T}$ cells considered to initiate and perpetuate the immune processes in MS, are found both in patients and healthy individuals. ${ }^{42,43}$ Thus, dysregulation of $\mathrm{T}$ cell apoptosis as a control mechanism might be crucial for the pathogenesis and heterogeneous course of MS. Apart from CD95mediated apoptosis currently being investigated with respect to its exact role in autoimmune diseases ${ }^{8}$ other death receptor/death ligand systems might also contribute to pathophysiologic processes.

Here, we studied the role of the TRAIL receptor/TRAIL system containing receptors which mediate apoptosis ${ }^{26-28}$ and those which block apoptosis. ${ }^{30-32,44} \mathrm{We}$ investigated the latter in autoreactive and foreign antigen-specific $T$ cells of MS patients and healthy individuals. In contrast to transformed Jurkat $T$ cells, (auto)antigen-specific $T$ cells were resistant to soluble TRAIL (Figure 1). Such a difference was also demonstrated in our previous work on monomeric soluble CD95 ligand. ${ }^{45}$ Notably, even trimerized soluble LZ-TRAIL ${ }^{46}$ was not capable of inducing apoptosis in the (auto)antigen-specific $T$ cells (Figure 1). The resistance towards the ligand was apparent, although we found expression of both death-mediating TRAIL receptors, TRAIL-R1 and TRAIL-R2, on the RNA and protein level (Figures 2 and 3). As overexpression of truncated TRAIL receptors was shown to inhibit TRAIL-induced apoptosis, ${ }^{27,29,31}$ we then investigated the distribution of deathblocking truncated TRAIL receptors in the (auto)antigenspecific $T$ cells derived from MS patients and healthy individuals. Our data demonstrate coexpression of death- 
inducing and death-blocking TRAIL receptors (Figures 3 and $5 \mathrm{c}$ ).

Furthermore, we studied the apoptotic cell death mediated by specific TRAIL-R1 and TRAIL-R2 antibodies in comparison to TRAIL. These agonistic antibodies were employed in order to assess a potential functional influence of the truncated on the death-inducing TRAIL receptors with respect to the apoptosis properties of TRAIL which binds all receptors. The auto(antigen)-specific $T$ cells were neither sensitive to TRAIL nor to direct apoptosis induction by agonistic TRAIL-R1 and TRAIL-R2 antibodies, whereas Jurkat $T$ cells readily underwent apoptosis when incubated with TRAIL or these antibodies (Figure 4). The amount of apoptosis in Jurkat $T$ cells induced by the agonistic antibodies was comparable to the ligand-induced apoptosis rate. These data indicate that there is no inhibition of apoptosis by the truncated TRAIL receptors, and that the resistance of the (auto)antigen-specific $\mathrm{T}$ cells is not conferred by these receptors.

So far, we found RNA and surface expression of TRAIL receptors 1-4 in both the autoreactive myelin-specific and foreign antigen-specific $T$ cell lines, and in both $T$ cell lines from MS patients and healthy individuals (Figures 3 and 5). Interestingly, a difference between MS patients and healthy donors was only present for the surface expression of TRAIL-R3, namely a higher expression of TRAIL-R3 in patients. Recently, it was postulated that several death ligands, including TRAIL, are involved in activation-induced cell death. ${ }^{47}$ In line with previous results in murine $T$ cells, we found a marked up-regulation of TRAIL surface expression in human antigen-specific $T$ cells when these were activated (Figure 5). ${ }^{48}$ Expression of death-inducing TRAIL-R1 and TRAIL-R2 was even downregulated in the antigen-specific $T$ cells upon activation (Figure 5).

In conclusion, we were interested whether, and to which extent, the TRAIL receptor/TRAIL system contributes to T cell homeostasis and is involved in autoimmunity, since evidence has been provided that the general mechanism of apoptosis and, in particular, failure of T cell apoptosis might be part of the pathogenesis of autoimmune diseases such as MS, a T cell-mediated disorder of the central nervous system. ${ }^{8}$ Up to now, mainly the CD95/CD95 ligand system, known to be important for activation-induced $\mathrm{T}$ cell death, has been studied in this context. For the first time, we report on the expression of agonistic and truncated TRAIL receptors in human (auto)antigen-specific T cells. Although autoreactive and foreign antigen-specific $T$ cells of MS patients and healthy individuals express death-inducing TRAIL receptors, soluble active TRAIL does not induce death in these cells independently of their antigen reactivity and the corresponding disease status. Our data provide no evidence for a protective role of the truncated TRAIL receptors in (auto)antigen-specific $T$ cells. ${ }^{27,29,31}$ This suggests that the role of TRAIL receptors in MS does not refer to regulation of $T$ cell vulnerability. Future studies should elucidate whether local elimination of autoreactive $T$ cells in the effector organ, the immune privileged central nervous system, might involve TRAIL-mediated apoptosis in MS.

\section{Materials and Methods}

\section{Materials and cell lines}

Human recombinant soluble TRAIL, ${ }^{48}$ a soluble TRAIL-kit from Alexis Corporation (San Diego, CA, USA; employed together with an enhancer antibody for multimerization) and trimerized soluble leucine zipper TRAIL (LZ-TRAIL), ${ }^{46}$ kindly provided by Immunex Corporation (Seattle, WA, USA), were used. The anti-APO-1 antibody ${ }^{49}$ was used in the presence of the crosslinker protein $A$. Cycloheximide $(\mathrm{CHX})$ was purchased from Sigma (Deisenhofen, Germany). Monoclonal antibodies specific for TRAIL and TRAIL receptors 1, 2, 3, 4 (M180, M270, M413, M430 and M444, respectively) were of the mouse IgG1 subclass; additionally, an agonistic antibody specific for TRAIL receptor 1 (M271) was employed for induction of apoptosis. Antibody specificity was determined by transient expression of the different receptors in CV-1 cells. These antibodies were obtained from Immunex Corporation. As isotype-matched control antibody a mouse IgG1 antibody was used (Sigma, Deisenhofen, Germany). Anti-CD3 antibody (OKT3) was obtained from the American Type Culture Collection (Manassas, VA, USA) and anti-CD28 antibody from Ancell (Bayport, MN, USA). Jurkat T lymphoma, LN18 and T98G glioma cell lines, ${ }^{36}$ cultured in RPMI supplemented with $2 \mathrm{mM}$ L-glutamine, $100 \mathrm{U} / \mathrm{ml}$ penicillin, $100 \mu \mathrm{g} / \mathrm{ml}$ streptomycin and $10 \%$ fetal calf serum, were used as human transformed cell lines in comparison to human antigen-specific $T$ cell lines.

\section{Human antigen-specific $\mathbf{T}$ cell lines}

Antigen-specific CD4+ $T$ cell lines were established using a modified 'split-well' protocol. ${ }^{45}$ Briefly, $2 \times 10^{5}$ peripheral blood mononuclear cells (PBMC) were seeded in $200 \mu \mathrm{l}$ medium (RPMI supplemented with $2 \mathrm{mM}$ L-glutamine, $100 \mathrm{U} / \mathrm{ml}$ penicillin, $100 \mu \mathrm{g} / \mathrm{ml}$ streptomycin and $5 \%$ pooled human $A B$ serum) in the presence of $20 \mu \mathrm{g} / \mathrm{ml}$ myelin basic protein (MBP) or $4 \mu \mathrm{g} / \mathrm{ml}$ tetanus toxoid (TT) in 96-well round bottom microtiter plates. After 7 days, $10 \mathrm{IU} / \mathrm{ml}$ recombinant human interleukin-2 (IL-2) (Proleukin, Eurocetus, Frankfurt, Germany) was added to the cultures. Five to 7 days thereafter, $100 \mu$ l were taken from each original well and split into two wells on a new plate. Irradiated (3000 rad) autologous PBMC $\left(1 \times 10^{5}\right)$ were added to each well of the master plate and to the split plate in the presence or absence of antigen. Specificity was tested by a standard proliferation assay. $\left[{ }^{3} \mathrm{H}\right]$ thymidine $(0.5 \mu \mathrm{Ci})$ (Amersham, Braunschweig, Germany) was added to each well of the split plate. Incorporation of radioactivity was measured after $18 \mathrm{~h}$ with a beta counter (Microbeta; Wallac, Turku, Finland). Specifically responding populations, with stimulation indexes greater than three, were selected for further expansion.

For RT-PCR and flow cytometric analysis of activated T cells a protocol employing antibodies to CD3 and CD28 was used. ${ }^{50}$ Cell culture plates were coated with anti-CD28 and anti-CD3 antibodies overnight at $10 \mu \mathrm{g} / \mathrm{ml}$ in PBS. After washing of the plates T cells were incubated for $24 \mathrm{~h}$ prior to assays.

\section{RT - PCR}

Isolation of RNA was performed using a total RNA purification kit (Peqlab, Erlangen, Germany). Possibly contaminating genomic DNA was removed by DNAse-digestion (Boehringer Mannheim, Mannheim, Germany). From $1 \mu \mathrm{g}$ of RNA, cDNA was synthesized using a firststrand CDNA synthesis kit (Pharmacia Biotech, Freiburg, Germany). The PCR conditions were as follows: TRAIL-R1 29 cycles, $45 \mathrm{~s} / 95^{\circ} \mathrm{C}$, $45 \mathrm{~s} / 60^{\circ} \mathrm{C}, 60 \mathrm{~s} / 72^{\circ} \mathrm{C}$, primer sequences ACTCGCTGTCCACTTTCGTCTCTGA (nucleotides 911-935) and 
CATCCCCTGGGCCTGCTGCTGTA (nucleotides 1200-1219); TRAIL-R2 28 cycles, $45 \mathrm{~s} / 95^{\circ} \mathrm{C}, 45 \mathrm{~s} / 60^{\circ} \mathrm{C}, 60 \mathrm{~s} / 72^{\circ} \mathrm{C}$, primer sequences GGGAGCCGCTCATGAGGAAGTT (nucleotides 10831104) and CTGGGTGATGTTGGATGGGAGAGT (nucleotides 14651488); TRAIL-R3 33 cycles, $45 \mathrm{~s} / 95^{\circ} \mathrm{C}, 45 \mathrm{~s} / 72^{\circ} \mathrm{C}, 45 \mathrm{~s} / 72^{\circ} \mathrm{C}$, primer sequences GAAGAATTTGGTGCCAATGCCACT (nucleotides 600623) and CTCTTGGACTTGGCTGGGAGATGT (nucleotides 11881224); TRAIL-R4 32 cycles, $45 \mathrm{~s} / 95^{\circ} \mathrm{C}, 45 \mathrm{~s} / 64^{\circ} \mathrm{C}, 60 \mathrm{~s} / 72^{\circ} \mathrm{C}$, primer sequences CAACTGGTGGGCTCCGAAAAG (nucleotides 12531273) and ACCGCATGTGGCCTAAAACGAC (nucleotides 15781599); Glyceraldehyde-3-phosphate-dehydrogenase (G3PDH) 26 cycles, $45 \mathrm{~s} / 95^{\circ} \mathrm{C}, 45 \mathrm{~s} / 54^{\circ} \mathrm{C}, 60 \mathrm{~s} / 72^{\circ} \mathrm{C}$, primer sequences GTCAACGGATTTGGTCGTATT (nucleotides 82-102) and AGTCTTCTGGGTGGCAGTGAT (nucleotides 601-621).

The PCR fragments were separated in $3 \%$ agarose gels and visualized by ethidium bromide. A cDNA fragment of the housekeeping gene G3PDH was amplified as reference for the relative expression of the other genes. For all genes, PCR protocols were standardized so that the cycle number ensured PCR-amplification was in its exponential phase. To quantify the expression of the TRAIL receptors, optical density (OD) was determined using BioDocll (Biometra, Göttingen, Germany) documentation system and Scanalytics ONE-Dscan software (Scanalytics Inc, Fairfax, VA, USA). Relative TRAIL receptor expression is presented as arbitrary value OD index, calculated as ratio of the integrated OD of the TRAIL receptor to the appropriate OD of G3PDH.

\section{Induction of cell death by recombinant human TRAIL or TRAIL-R1- and -R2-specific monoclonal antibodies}

Recombinant LZ-TRAIL was used at $2 \mu \mathrm{g} / \mathrm{ml}$. For induction of apoptosis with TRAIL-R1 (M271) and -R2 (M413)-specific monoclonal antibodies, 96 well plates were coated overnight at $4^{\circ} \mathrm{C}$ with the indicated concentrations of the monoclonal antibodies. $1.5 \times 10^{5} \mathrm{~T}$ cells were subsequently added to $3 \times$ PBS-washed wells.

\section{DNA fragmentation}

For quantitative analysis of DNA fragmentation, $10^{5}$ cells were treated according to the protocol described by Nicoletti. ${ }^{51}$ Briefly, a hypotonic fluorochrome solution (propidium iodide $50 \mu \mathrm{g} / \mathrm{ml}$ in $0.1 \%$ sodium citrate and $0.1 \%$ Triton $\mathrm{X}-100$ ) was added to $10^{5}$ cells, followed by incubation overnight at $4^{\circ} \mathrm{C}$. The level of the hypodiploid DNA peak was determined as percentage of total events by flow cytometry. Data are presented as specific DNA fragmentation (with stimulus/control).

\section{DEVD-amc-cleaving caspase activity}

To measure DEVD-amc-cleaving caspase activity, $10^{5} \mathrm{~T}$ cells were plated in 96-well flat bottom plates, incubated with various stimuli for $3 \mathrm{~h}$, or $6 \mathrm{~h}$ in serum-free medium (AIM-V), and subsequently lysed in lysis buffer ( $60 \mathrm{mM} \mathrm{NaCl}, 5 \mathrm{mM}$ Tris-HCl, $2.5 \mathrm{mM}$ EDTA, 0.25\% NP40) for $10 \mathrm{~min}$. The fluorogenic caspase substrate DEVD-amc $(20 \mu \mathrm{M})$ (BIOMOL, Hamburg, Germany) was added to the lysates and fluorescence was measured after 30 and $60 \mathrm{~min}$ at $360 \mathrm{~nm}$ excitation and $480 \mathrm{~nm}$ emission wavelengths using a CytoFluor 2400 cytofluorometer (Millipore Corp., Eschborn, Germany). The amount of caspase activity is given as fluorescence units.

\section{Flow cytometry}

T cells ( $10^{5}$ per sample) were stained with $10 \mu \mathrm{g} / \mathrm{ml}$ of monoclonal mouse lgG1 antibodies for $30 \mathrm{~min}$ at $4^{\circ} \mathrm{C}$ in PBS containing $0.01 \% \mathrm{Na}$ - azide and $0.25 \%$ bovine serum albumin. Washed cells were incubated with phycoerythrin (PE)-labeled secondary $F\left(a b^{\prime}\right)_{2}$ fragments of a goat-anti-mouse antiserum (DAKO, Hamburg, Germany) for 30 min. Samples were measured using a FACScan flow cytometer and analyzed using the Cellquest software (Becton-Dickinson, Mountain View, Ca, USA). Values are expressed as specific fluorescence intensity, calculated by histogram statistics and defined by the percentage of fluorescence intensity with a certain antibody excluding the fluorescence intensity with the appropriate control antibody. A maximal background staining of $5 \%$ was tolerated within the region of specific fluorescence intensity.

\section{Acknowledgements}

We thank Ulrike Grieger, Heiko Stahl and Eva Rieser for expert technical assistance and Orhan Aktas for help with preparing the manuscript. F Zipp was supported by grants from the Deutsche Forschungsgemeinschaft ZI 448/7-1, the Gemeinnützige Hertie-Stiftung, and the Deutsche Multiple Sklerose-Gesellschaft. H Walczak received a fellowship from the Bundesministerium für Forschung und Technologie (AIDSStipendium).

\section{References}

1. Lenardo M, Ka-Ming Chan F, Hornung F, McFarland H, Siegel R, Wang J and Zheng L (1999) Mature Lymphocyte Apoptosis-Immune Regulation in a Dynamic and Unpredictable Antigenic Environment. Annu. Rev. Immunol. 17: $221-253$

2. Pender MP (1999) Activation-induced apoptosis of autoreactive and alloreactive T lymphocytes in the target organ as a major mechanism of tolerance. Immunol. Cell Biol 77: 216-223

3. Alderson MR, Tough TW, Davis-Smith T, Braddy S, Falk B, Schooley KA, Goodwin RG, Smith CA, Ramsdell F and Lynch DH (1995) Fas ligand mediates activation-induced cell death in human T lymphocytes. J. Exp. Med. 181: 71-77

4. Dhein J, Walczak H, Bèumler C, Debatin KM and Krammer PH (1995) Autocrine T-cell suicide mediated by APO-1(Fas/CD95). Nature 373: 438-441

5. Ju ST, Panka DJ, Cui H, Ettinger R, El-Khatib M, Sherr DH, Stanger BZ and Marshak-Rothstein A (1995) Fas (CD95)/FasL interactions required for programmed cell death after T cell-activation. Nature 373: 444-448

6. D'Souza SD, Bonetti B, Balasingam V, Cashman NR, Barker PA, Troutt AB, Raine CS and Antel JP (1996) Multiple sclerosis: Fas signaling in oligodendrocyte cell death. J. Exp. Med. 184: 2361-2370

7. Dowling P, Shang G, Raval S, Menonna J, Cook S and Husar W (1996) Involvement of the CD95 (APO-1/Fas) receptor/ligand system in multiple sclerosis brain. J. Exp. Med. 184: 1513-1518

8. Zipp F, Krammer PH and Weller M (1999) Immune (dys)regulation in multiple sclerosis: role of the CD95/CD95 ligand system. Immunol. Today 20: 550-554

9. Schmied M, Breitschopf H, Gold R, Zischler H, Rothe G, Wekerle H and Lassmann H (1993) Apoptosis of T lymphocytes in experimental autoimmune encephalomyelitis: Evidence for programmed cell death as a mechanism to control inflammation in the brain. Am. J. Pathology 143: 446-452

10. Critchfield JM, Racke MK, Zuniga-PfluckerJC, Cannella B, Raine CS, Goverman $\mathrm{J}$ and Lenardo MJ (1994) T cell deletion in high antigen dose therapy of autoimmune encephalomyelitis. Science 263: 1139-1143

11. Ishigami T, White CA and Pender MP (1998) Soluble antigen therapy induces apoptosis of autoreactive $T$ cells preferentially in the target organ rather than in the peripheral lymphoid organs. Eur. J. Immunol. 28: 1626-1635

12. Zhou T, Song L, Yang P, Wang Z, Lui D and Jope RS (1999) Bisindolylmaleimide VIII faciltates Fas-mediated apoptosis and inhibits T cell-mediated autoimmune diseases. Nat. Med. 5: 42-48

13. Malipiero U, Frei K, Spanaus K-S, Agresti C, Lassmann H, Hahne M, Tschopp J, Eugster H-P and Fontana A(1997) Myelin oligodendrocyte glycoprotein-induced encephalomyelitis is chronic/relapsing in perforin knockout mice, but monophasic in Fas- and Fas ligand-deficient Ipr and gld mice. Eur. J. Immunol. 27: $3151-3160$ 
14. Waldner H, Sobel RA, Howard E and Kuchroo VK (1997) Fas-and FasL-deficient mice are resistant to induction of autoimmune encephalomyelitis. J. Immunol. 159: $3100-3103$

15. Sabelko KA, Kelly KA, Nahm MH, Cross AH and Russell JH (1997) Fas and Fas ligand enhance the pathogenesis of experimental allergic encephalomyelitis, but are not essential for immune privilege in the central nervous system. J. Immunol. 159: $3096-3099$

16. Zipp F, Weller M, Calabresi PA, Frank JA, Bash CN, Dichgans J, McFarland H and Martin R (1998) Increased serum levels of soluble CD95 (APO1/Fas) in relapsing remitting multiple sclerosis. Ann. Neurol. 43: 116-120

17. Zipp F, Otzelberger K, Dichgans J, Martin R and Weller M (1998) Serum CD95 of multiple sclerosis patients protects from CD95-mediated apoptosis. J. Neuroimmunol. 86: 151-154

18. Ciusani E, Frigerio S, Gelati M, Corsini E, Dufour A, Nespolo A, La Mantia L, Milanese C, Massa G and Salmaggi A (1998) Soluble Fas (Apo-1) levels in cerebrospinal fluid of multiple sclerosis patients. J. Neuroimmunol. 82: 5-12

19. Zang YCQ, Kozovska MM, Hong J, Li S, Mann S, Killian JM, Rivera VM and Zhang JZ (1999) Impaired apoptotic deletion of myelin basic protein-reactive T cells in patients with multiple sclerosis. Eur. J. Immunol. 29: 1692-1700

20. Macchi B, Matteucci C, Nocentini U, Caltagirone C and Mastino A (1999) Impaired apoptosis in mitogen-stimulated lymphocytes of patients with multiple sclerosis. Neuroreport. 10: 399-402

21. Sabelko-Downes KA, Cross AH and Russell JH (1999) Dual role for Fas ligand in the initiation of and recovery from experimental allergic encephalomyelitis. J. Exp. Med. 189: 1195-1205

22. Klas C, Debatin KM, Jonker RR and Krammer PH (1993) Activation interferes with the APO-1 pathway in mature human T cells. Int. Immunol. 5: 625-630

23. Peter ME, Kischkel FC, Scheuerpflug CG, Medema JP, Debatin KM and Kramer $\mathrm{PH}$ (1997) Resistance of cultured peripheral T cells towards activation-induced cell death involves a lack of recruitment of FLICE (MACH/caspase 8) to the CD95 death-inducing signaling complex. Eur. J. Immunol. 27: 1207-1212

24. Wiley SR, Schooley K, Smolak PJ, Din WS, Huang CP, Nicholl JK, Sutherland GR, Smith TD, Rauch C, Smith CA and Goodwin RG (1995) Identification and characterization of a new member of the TNF family that induces apoptosis. Immunity 3: 673-682

25. Pitti RM, Marsters SA, Ruppert S, Donahue CJ, Moore A and Ashkenazi A (1996) Induction of apoptosis by Apo-2 ligand, a new member of the tumor necrosis factor cytokine family. J. Biol. Chem. 271: 12687-12690

26. Pan G, O'Rourke K, Chinnaiyan AM, Gentz R, Ebner R, Ni J and Dixit VM (1997) The receptor for the cytotoxic ligand TRAIL. Science 276: 111-113

27. Sheridan JP, Marsters S, Pitti RM, Gurney A, Skubatch M, Baldwin D, Ramakrishnan L, Gray CL, Baker K, Wood WI, Goddard AD, Godowski P and Ashkenazi A (1997) Control of TRAIL-induced apoptosis by a family of signaling and decoy receptors. Science 277: 818-821

28. Walczak H, Degli-Esposti MA, Johnson RS, Smolak PJ, Waugh JY, Boiani N, Timour MS, Gerhart MJ, Schooley KA, Smith CA, Goodwin RG and Rauch CT (1997) TRAIL-R2: a novel apoptosis-mediating receptor for TRAIL. EMBO J. 16 $5386-5397$

29. Pan G, Ni J, Wei Y, Yu G, Gentz R and Dixit VM (1997) An antagonist decoy receptor and a death domain-containing receptor for TRAIL. Science 277: 815818

30. Mongkolsapaya J, Cowper AE, Xu XN, Morris G, McMichael AJ, Bell J and Screaton GR (1998) Lymphocyte inhibitor of TRAIL (TNF-related apoptosisinducing ligand): a new receptor protecting lymphocyte from the death ligand TRAIL. J. Immunol. 160: 3-6

31. Degli-Esposti MA, Dougall WC, Smolak PJ, Waugh JY, Smith CA and Goodwin RG (1997) The novel receptor TRAIL-R4 induces NF-kappaB and protects against TRAIL-mediated apoptosis, yet retains an incomplete death domain Immunity 7: 813-820

32. Marsters SA, Sheridan JP, Pitti RM, Huang A, Skubatch M, Baldwin D, Yuan J, Gurney A, Goddard AD, Godowski P and Ashkenzai A (1997)A novel receptor for Apo2L/TRAIL contains a truncated death domain. Curr. Biol. 7: 1003-1006
33. Schneider P, Thome M, Burns K, Bodmer J-L, Hofman K, Kataoka T, Holler Nand Tschopp J (1997) TRAIL receptors 1(DR4) and 2 (DR5) signal FADD-dependent apoptosis and activate NF-kappaB. Immunity 7: 831-836

34. Jeremias I, Herr I, Boehler T and Debatin KM (1998) TRAIL/Apo-2-ligandinduced apoptosis in human T cells. Eur. J. Immunol. 28: 143-152

35. Marsters SA, Sheridan JP, Pitti RM, Huang A, Skubatch M, Baldwin D, Yuan J, Gurney A, Goddard AD, Godowski P and Ashkenazi A (1996) Activation of apoptosis by Apo-2 ligand is independent of FADD but blocked by CrmA. Curr. Biol. 6: $750-752$

36. Rieger J, Naumann U, Glaser T, Ashkenazi A and WellerM (1998) APO2 ligand: a novel lethal weapon against malignant glioma? FEBS Lett. 427: 124-128

37. Nagata $S$ and Golstein P (1995) The Fas death factor. Science 267: 1449-1456

38 Fisher GH, Rosenberg FJ, Straus SE, Dale JK, Middelton LA, Lin AY, Strober W, Lenardo MJ and Puck JM (1995) Dominant interfering Fas gene mutations impair apoptosis in a human autoimmune lymphoproliferative syndrome. Cell 81:935946

39. Rieux-LaucatF, Le DeistF, Hivroz C, Roberts IAG, Debatin KM, Fischer A and de Villartay JP (1995) Mutations in Fas associated with human lymphoproliferative syndrome and autoimmunity. Science 268: 1347-1349

40. Drappa J, Vaishnaw AK, Sullivan KE, Chu JL and Elkon KB (1996) Fas gene mutations in the Canale-Smith syndrome, an inherited lymphoproliferative disorder associated with autoimmunity. N. Engl. J. Med. 335: 1643-1649

41. Le Deist F, Emile JF, Rieux-Laucat F, Benkerrou M, Roberts I, Brousse N and Fischer A (1996) Clinical, immunological, and pathological consequences of Fas-deficient conditions. Lancet 348: 719-723

42. Hohlfeld R, Meinl E, Weber F, Zipp F, Schmidt S, Sotgiu S, Goebels N, Voltz R, Spuler S, Iglesias A and Wekerle H (1995) The role of autoimmune Tlymphocytes in the pathogenesis of multiple sclerosis. Neurology 45: S33-S38

43. Martin R, McFarland HF and McFarlin DE (1992) Immunological aspects of demyelinating diseases. Annu. Rev. Immunol. 10: 153-187

44. Degli-Esposti MA, Smolak PJ, Walczak H, Waugh J, Huang C-P, DuBose RF, Goodwin RG and Smith CA (1997) Cloning and characterization of TRAIL-R3, a novel member of the emerging TRAIL receptor family. J. Exp. Med. 186: 11651170

45. Zipp F, Martin R, Lichtenfels R, Roth W, Dichgans J, Krammer PH and Weller M (1997) Human autoreactive and foreign antigen-specific T cells resist apoptosis induced by soluble recombinant CD95 ligand. J. Immunol. 159: 2108-2115

46. Walczak H, Miller RE, Ariail K, Gliniak B, Griffith TS, Kubin M, Chin W, Jones J, Woodward A, Le T, Smith C, Smolak P, Goodwin RG, Rauch CT, Schuh JACL and Lynch DH (1990) Tumoricidal activity of tumor necrosis factor-related apoptosis-inducing ligand in vivo. Nat. Med. 5: 157-163

47. Martinez LM, Alava MA, Gamen S, Kim KJ, Chuntharapai A, Pineiro A, Naval J and Anel A (1998) Involvement of APO2 ligand/TRAIL in activation-induced death of Jurkat and human peripheral blood T cells. Eur. J. Immunol. 28: 2714 2725

48. Mariani SM and Krammer PH (1998) Differential regulation of TRAIL and CD95 ligand in transformed cells of the T and B lymphocyte lineage. Eur. J. Immunol. 28: $973-982$

49. Trauth BC, Klas C, Peters AMJ, Matzku S, Müller P, Falk W, Debatin KM and Krammer PH (1989) Monoclonal antibody-mediated tumor regression by induction of apoptosis. Science 245: 301-305

50. Riddell SR and Greenberg PD (1990) The use of anti-CD3 and anti-CD28 monoclonal antibodies to clone and expand human antigen-specific T cells. J. Immunol. Methods 128: 189-201

51. Nicoletti I, Migliorati G, Pagliacci MC, Grignani F and Riccardi C (1991) A rapid and simple method for measuring thymocyte apoptosis by propidium iodide staining and flow cytometry. J. Immunol. Methods 139: 271-279 